\title{
Academic Success Factors: An IT Student Perspective
}

\author{
Aimao Zhang and Cheryl L. Aasheim \\ Georgia Southern University, Statesboro, GA, USA \\ aimao@georgiasouthern.edu caasheim@georgiasouthern.edu \\ Executive Summary
}

Numerous studies have identified causal factors for academic success. Factors vary from personal factors, such as cognitive style (McKenzie \& Schweitzer, 2001), to social factors, such as culture differences (Aysan, Tanrı̈ğen, \& Tanrı̈ğen, 1996). However, in these studies it is researchers who theorized the causal dimensions and hypothesized the causal factors. Students were passive objects used to test the theories or to validate the hypotheses. Each researcher may have developed his or her own scheme of causal structure. These structures are not necessarily identical among researchers nor are they the same as those of students. This study has two objectives. The first is to combine the factors that contribute to academic success that have been identified in the literature and to unify them under a single framework. This is achieved by reviewing the existing literature on academic success and on categorization of academic success factors in order to develop the framework.

The second objective is to add the IT student perspective to the framework. That is to find out what factors are perceived by students as relevant to their academic success and to determine which are the most important. To this end, two surveys were administered to IT students. In the first survey, students identified causal factors related to their own academic success. In the second survey, students ranked factors according to importance. Students did not list any factors that had been previously presented in research. However, they did identify them at a more detailed level (for example, literature might look at effort as a factor, where students listed several activities that involve effort). However, students did not list some factors as important to their success that had been previously identified in the literature, most notably intelligence.

The detailed results for the two surveys are presented and discussed. Recommendations are made for institutions and faculty based on the results obtained.

Keywords: academic success factors, IT education, educational policies, college students

\section{Introduction}

Material published as part of this publication, either on-line or in print, is copyrighted by the Informing Science Institute. Permission to make digital or paper copy of part or all of these works for personal or classroom use is granted without fee provided that the copies are not made or distributed for profit or commercial advantage AND that copies 1) bear this notice in full and 2) give the full citation on the first page. It is permissible to abstract these works so long as credit is given. To copy in all other cases or to republish or to post on a server or to redistribute to lists requires specific permission and payment of a fee. Contact Publisher@InformingScience.org to request redistribution permission.
A success or failure often triggers us to search for the factors that explain the outcome. There are many causal factors associated with any given event. However, we are usually interested in a particular type of event and the causal factors associated with it. In the case of educators, causal factors salient to academic success or failure are of particular interest. 
Academic success, particularly as it relates to IT-related degree programs, is an important topic from the U.S. national perspective.

"Leadership in science and technology - and networking and information technology (NIT) in particular - is essential to the Nation's global competitiveness and economic prosperity. ... However, continuation of America's strong position in developing and adopting new networking and information technology is not assured. Other nations have recognized the value of NIT leadership and are mounting challenges. ..." (President's Council on Science and Technology, 2007, p.9)

For network and IT specialists in particular, the U.S. is concerned that despite the growth in the supply of workers in response to the rising demand in the next decade, there will be shortfalls in the number of highly qualified workers in these areas (President's Council on Science and Technology, 2007). According to the U.S. Department of Labor the demand for employment in ITrelated professions will grow much faster than the average for all occupations through to the year 2018. The Bureau of Labor Statistics projects a 53\% increase between 2008 and 2018 in the number of jobs for network systems and data communications analysts, $23 \%$ for network and computer systems administrators, $20 \%$ for database administrators, and $17 \%$ for computer and information systems managers (Bureau of Labor Statistics, 2010a, 2010b). The aforementioned jobs require at least a Bachelor's degree. Therefore, recruiting and successfully graduating qualified students with a postsecondary education in these high growth and high demand career areas is important to the overall success of organizations in the U.S.

Given the high demand coupled with the declining enrollments in IS/IT programs nationwide, factors leading to the success of students in those programs are of particular interest to IS and IT educators. Programs with low enrollments are vulnerable to being cut, especially in light of declining budgets in higher education due to the poor economy. Any effort to improve the success, and thereby the retention, of students already enrolled could help improve the decline in the number of students who eventually graduate with an IS or IT major.

There are numerous studies identifying causal factors relating to academic success (see for example, Hanushek, 1996; Kinshuk \& McNab, 2006; McKenzie \& Schweitzer, 2001). However, the different research streams are isolated, and factors identified have not been integrated into an overall scheme. In addition, in academic success literature most factors are hypothesized by researchers, rather than by students. In other words, the approach used in previous studies represents the researchers' perspective, rather than the students'. The approach of the researcher proposing the causal factors related to academic success is meritorious as they have the expertise to do so. However, there could be important, relevant factors not examined in the literature that are missing only because students have not been asked directly what contributes to their academic success.

Given the importance of academic success, particularly for students in IT-related degree programs, the objective of this study is to contribute to the existing body of literature by organizing the various streams of research into a generalized integrated framework. In addition, the student viewpoint on factors related to their own academic success will be added to what is currently understood about factors contributing to academic success. Students are asked directly, in an openended survey, what factors contribute to their success. They are then asked to rank their perceptions on factors contributing to academic success derived from the literature augmented by factors identified in the first open-ended survey. The current research provides a more integrated view of the causal effect of academic success as it combines student perceptions with those factors identified in previous research studies. 


\section{Literature Review}

There are many indicators of academic success, including, but not limited to, GPA, graduation rate, retention rate, annual salary the first year after graduation, and placement percentage of graduates. However academic success is defined, it is important for institutions to understand the most salient factors that affect academic success of their student body in order to improve that success rate. In addition, integrating the factors identified into a single framework will add to the overall understanding of how the factors are related. To this end, existing literature about academic success factors is reviewed.

In order to develop the framework, existing literature needs to be examined for an inventory of factors currently identified as important to academic success. The literature also needs to be examined to determine if researchers have already developed classification or categorization schemes that can be used as a starting point for the framework. In addition, if there are any studies that use empirical evidence to validate these classification schemes, these need to be reviewed as well. Therefore, the literature review consists of three parts. First, literature related to how academic success factors are categorized and how the categorization is validated by empirical studies is presented. The second section reviews studies that investigated a wide range of academic success factors, from personal factors to social factors. Finally, issues with previous research results and the lack of student perspective in most research efforts are discussed.

\section{Categorization of Academic Success Factors}

As a starting point for determining how to categorize success factors, attribution theory, a general framework that is used to categorize causal factors in many research fields, including political elections, sports events, or academic performance is examined. In his earlier work, Weiner (1974) applied attribution theory to achievement, identifying two dimensions with which to categorize causal factors: internal/external and stable/unstable. This framework has 4 categories of factors:

- Internal/Stable factor (i.e., ability and good genes).

- Internal/Unstable factor (i.e., effort and interest).

- External/Stable factor (i.e., difficulty of course or subject).

- External/Unstable factor (i.e., luck and opportunity).

Table 1 shows the 2 x 2 categorization with ability, effort, luck, and task difficulty postulated in it.

Table 1: A 2 x 2 Scheme for the Perceived Causes of Outcomes (Weiner, 1974).

\begin{tabular}{|c|c|c|}
\hline & Internal & External \\
\hline Stable & Ability & Task Difficulty \\
\hline Unstable & Effort & Luck \\
\hline
\end{tabular}

In 1979, Weiner added another dimension, controllability, to his model (Weiner, 1979). In this later model, all external factors are considered to be uncontrollable. Internal factors can be controllable or uncontrollable (see Table 2). For instance, the height of a basketball player is considered an uncontrollable internal factor while the skill of the player is considered controllable through training. 
Table 2: Third Dimension - Controllability

\begin{tabular}{|c|c|c|}
\hline \multirow{2}{*}{ Stable } & Internal & External \\
\cline { 2 - 2 } & Controllable & \multirow{2}{*}{ Uncontrollable } \\
\hline \multirow{2}{*}{ Unstable } & Uncontrollable & \\
\cline { 2 - 2 } & Controllable & Uncontrollable \\
\hline
\end{tabular}

\section{Empirical Evidence Supporting the Categorization of Factors}

Several studies, both education related (Meyer \& Koelbl, 1982; Schoeneman \& Curry, 1990) and non-education related (Roberts \& Pascuzzi, 1979), have validated the dimensions proposed by Weiner's model. In a study conducted by Schoeneman and Curry (1990), 466 undergraduate students attributed the causal factors of their behavior changes to three dimensions: internal, unstable, and controllable. Roberts and Pascuzzi (1979) conducted an experiment and asked 346 college students to identify causal factors that contributed to the outcomes of various sports situations. Forty-five percent (45\%) of the time, the subjects listed ability, effort, luck, and task difficulty as the causal factors. When asked to categorize causal factors, these subjects were able to place factors within the four cells of the Weiner model 100\% of the time (Roberts \& Pascuzzi, 1979). These studies provided evidence in support of the $2 \times 2$ categorization matrix proposed by Weiner (1974). Other studies assumed the existence of the dimensions and tested the level of impact from each quadrant of the 2 x 2 matrix, i.e., levels of impact of ability, effort, luck, or task difficulty on the outcomes of events. Kovenklioglu and Greenhaus (1978) found that college students attributed their successes in chemistry tests to ability and not to luck, but attributed their failures to effort and not to ability. These early studies on categorization of success factors and the validation of these categories provide an overall structure for reviewing the literature as well as a foundation for the framework proposed in this paper.

\section{Factors Investigated in Previous Studies}

The factors identified in previous studies formed several groups that can be categorized as factors at the individual, course, family, school, and macro level. At the individual level, a group of psychologists examined how student's cognitive style, anxiety, and loneliness influenced academic success (McKenzie \& Schweitzer, 2001; Ross, Drysdale, \& Schulz, 2001).

At the course level, instructors' behavior, teaching methods, subject matter, and student-teacher interaction were related to academic success (Aysan et al., 1996; Mayer \& Patriarca, 2007). At the family level, family demographic characteristics were observed to have a positive association with academic success (Demeulemeester \& Rochat, 1995; McKenzie \& Schweitzer, 2001). For instance, a "socio-cultural" learning environment in web development course was proved to be beneficial to African American students, especially female African American students (Seay, 2004).

At the school level, focus was on suspension and retention policies, school spending, and resources (Denton, Morris, \& Tooke, 1981; Hulse, Chenowith, Lebedovych, Dickinson, Cavanaugh, \& Garrett, 2007). At the macro level, academic success was associated with economic growth and social cohesion (Hanushek \& Kimko, 2000).

To provide a summarized view of academic success research, Table 3 highlights the factors investigated by the previous studies. The order of the factors in Table 3 is arranged from personal factors to social factors. 
Table 3: Factors Investigated Related to Academic Success

\begin{tabular}{|c|c|}
\hline Factors & References \\
\hline $\begin{array}{l}\text { Cognitive learning styles: concrete sequential, abstract se- } \\
\text { quential, abstract random, and concrete random. }\end{array}$ & Ross et al., 2001 \\
\hline $\begin{array}{l}\text { Learning styles: perceptual modality, distractibility, meta- } \\
\text { cognition, analytic global tendency. }\end{array}$ & Zhang \& RiCharde, 1997 \\
\hline Ability, effort, task, luck & $\begin{array}{l}\text { Boekaerts, Otten, \& Voeten, } \\
2003\end{array}$ \\
\hline Ability, effort, task, luck, culture, gender, course subject & Yan \& Gaier, 1994 \\
\hline Reading and writing abilities, task difficulty, study habits & Ritchey \& Lewis, 1986 \\
\hline Effort, self-efficacy, loneliness, coherence, mood, hope & Lackaye \& Margalit, 2006 \\
\hline Goal orientation, self-efficacy and self-regulation & Niemczyk \& Savenye, 2001 \\
\hline Self esteem & Feick \& Rhodewalt, 1997 \\
\hline Anxiety, locus control, critical thinking & Hulse et al., 2007 \\
\hline Academic, psychosocial, cognitive, demographic factors & McKenzie \& Schweitzer, 2001 \\
\hline $\begin{array}{l}\text { Age, gender, type of high school attended, nationality, paren- } \\
\text { tal education, number of siblings, siblings' education, living } \\
\text { arrangement changes }\end{array}$ & Demeulemeester \& Rochat, 1995 \\
\hline $\begin{array}{l}\text { Parental education and employment, student's procrastination } \\
\text { of task, value of task, anxiety, classroom climate, support } \\
\text { from peers, task load, instruction quality }\end{array}$ & Bruinsma \& Jansen, 2007 \\
\hline $\begin{array}{l}\text { Family income, parental education, parental involvement and } \\
\text { hostility }\end{array}$ & Melby \& Conger, 1996 \\
\hline $\begin{array}{l}\text { Parental practices in support, reasoning, punitiveness, moni- } \\
\text { toring, and autonomy granting }\end{array}$ & Henry, Martinko, \& Pierce, 1993 \\
\hline $\begin{array}{l}\text { Three types of orientation (self, interaction, task), four cogni- } \\
\text { tive styles(concrete experience, reflective observation, ab- } \\
\text { stract conceptualization, active experimentation), attitude to- } \\
\text { ward course and computer use; philosophy in (vocation, aca- } \\
\text { demic, social interaction, individual identity) }\end{array}$ & Kevin \& Liberty, 1975 \\
\hline Support networks, depression, life events & Blumberg, 1984 \\
\hline Field of study, quantity of course work, and GPA of teacher & Denton et al., 1981 \\
\hline $\begin{array}{l}\text { Amount of time spent, teacher characteristics, teacher/student } \\
\text { interaction, classroom control, instructional (organization, } \\
\text { integration, materials, articulation) }\end{array}$ & Connolly \& McGrail, 1978 \\
\hline $\begin{array}{l}\text { Teachers' behavior, teaching methods, commitment to study, } \\
\text { learning environment, content of study, psychological prob- } \\
\text { lems, relationship with family, concern with field of study and } \\
\text { future career, time management. }\end{array}$ & Aysan et al., 1996 \\
\hline
\end{tabular}




\begin{tabular}{|c|c|}
\hline $\begin{array}{l}\text { Relationship with teacher, interests in assignments, feeling of } \\
\text { competence }\end{array}$ & Daniels \& Arapostathis, 2005 \\
\hline Student-teacher relation and interaction & McGregor, 2007 \\
\hline Perceived faculty support & Shelton, 2003 \\
\hline Teacher salaries, school spending, reduced-price or free lunch & $\begin{array}{l}\text { Costrell, Hanushek, \& Loeb, } \\
2008\end{array}$ \\
\hline $\begin{array}{l}\text { School expenditure, teacher ability, teacher education, teacher } \\
\text { experience, teacher salary, teacher/student ratio, school size }\end{array}$ & $\begin{array}{l}\text { Greenwald, Hedges, \& Laine, } \\
1996\end{array}$ \\
\hline Class size & $\begin{array}{l}\text { Ehrenberg, Brewer, Gamoran, \& } \\
\text { Willms, } 2001\end{array}$ \\
\hline $\begin{array}{l}\text { Study time influences academic performance, but is moder- } \\
\text { ated by study habits. Planning/scheduling not as important } \\
\text { for short term success. }\end{array}$ & Nonis \& Hudson, 2010 \\
\hline $\begin{array}{l}\text { Social climate, academic facilities, co-curricular activities, } \\
\text { advising, getting into classes (registration, financial aid, } \\
\text { course availability, textbook) }\end{array}$ & Wince \& Borden, 1995 \\
\hline $\begin{array}{l}\text { Institutional factors, academic integration, social integration, } \\
\text { campus climate, financial status }\end{array}$ & $\begin{array}{l}\text { Volkwein, Valle, Parmley, } \\
\text { Blose, \& Zhou, } 2000\end{array}$ \\
\hline Accountability policy & Hanushek \& Raymond, 2005 \\
\hline Tracking policy to place and group students base on ability & Hanushek \& Wößmann, 2006 \\
\hline Success of athletic programs & Mixon \& Treviño, 2005 \\
\hline Retention policy & Bowman, 2005 \\
\hline Suspending policy & $\begin{array}{l}\text { Howard, Borland, Johnson, \& } \\
\text { Baker, } 2001\end{array}$ \\
\hline Government policy: education accountability in Alabama & Mathews \& Hackett, 1997 \\
\hline $\begin{array}{l}\text { State program: Families and Communities Equals Success in } \\
\text { North Carolina }\end{array}$ & $\begin{array}{l}\text { Fernandez, Campbell, \& Hon- } \\
\text { ness, } 2000\end{array}$ \\
\hline $\begin{array}{l}\text { Societal health including human capital, knowledge capital } \\
\text { and health capital }\end{array}$ & Grossman, 2008 \\
\hline Social and economical factors & Matuszek \& Haskin, 1978 \\
\hline Social cohesion & Gradstein \& Justman, 2000 \\
\hline
\end{tabular}

\section{Issues in Previous Studies and Lack of Student Perspective}

The authors have not found any studies that were based on student perspectives. The typical research process was to hypothesize a theory with independent and dependent variables, design a questionnaire, collect measurements on students, and generate a result.

Another problem in the academic success research is the tautology where one dependent variable is used to test another dependent variable. For instance, success in one course is used to predict success in another (Brookshire, Crews, \& Brown, 2009). The framework in proposed in this paper will help researchers identify independent variables for the proposed categories. 
Many studies involving pre-college students use secondary data, such as Public Elementary Secondary Education Finance Data from http://www.census.gov/govs/school/. At the college level, some studies have used well established scales, such as the achievement motive scale and the Watson Glaser critical thinking appraisal (Mehrabian, 1968), and many studies used selfdesigned questionnaires.

To summarize the review of the literature, academic success factors have multiple categories, research has multiple levels, within a single level, findings were not conclusive, and the student perspective was not considered.

\section{Proposed Generalized Framework}

Based on the review of the literature, a generalized framework for categorizing the factors related to academic success is proposed. In the framework, factors can be categorized into seven groups:

- Personal (motivation, commitment, study, etc.)

- Family (income level, marital status, number of siblings, etc.)

- Peer-related (classmates, study group members, friends, etc.)

- Subject/content (course structure, grading policy, textbook, etc.)

- Institutional agent (faculty, advisor, staff, etc.)

- Institutional (location, program reputation, scholarships, etc.)

- Social (economy, crime rate, etc.)

The groups start at the personal level and move to broader levels such as at the institutional and social level. Weiner's model is used to further categorize each of the seven groups into six dimensions: internal/external, stable/unstable, controllable/uncontrollable of internal factors. This ultimately leads to 42 categories $(7 \times 6)$. Table 4 provides examples of 6 categories for personal factors.

In the current study, a subset of the model proposed in Figure 1 is used. We combined the factors generated from the first survey (in Table 5) and the factors from the literature review (Table 3), and formed seven groups of factors(in Table 6). The factor groups corresponded to factors proposed in the generalized framework in Figure 1: personal, subject/content, institutional agent, institutional, and social. The authors then applied Weiner's model to the personal factors to create three subgroups. The seven resulting categories are identified in Table 6 as the headings for each group of factors.

Table 4: Examples of Various Dimensions in the Proposed Generalized Framework

\begin{tabular}{|l|l|l|}
\hline Factor Group & \multicolumn{1}{|c|}{ Dimension } & \multicolumn{1}{c|}{ Examples } \\
\hline \multirow{4}{*}{ Personal } & Internal/Stable/Controllable & Basketball skills due to training \\
\cline { 2 - 3 } & Internal/Stable/Uncontrollable & Player's height due to gene \\
\cline { 2 - 3 } & Internal/Unstable/Controllable & Effort invested in studying \\
\cline { 2 - 3 } & Internal/Unstable/Uncontrollable & Mode at the day of exam \\
\cline { 2 - 3 } & External/Stable/Uncontrollable & Difficulty of the exam \\
\cline { 2 - 3 } & External/Unstable/Uncontrollable & Luck \\
\hline
\end{tabular}




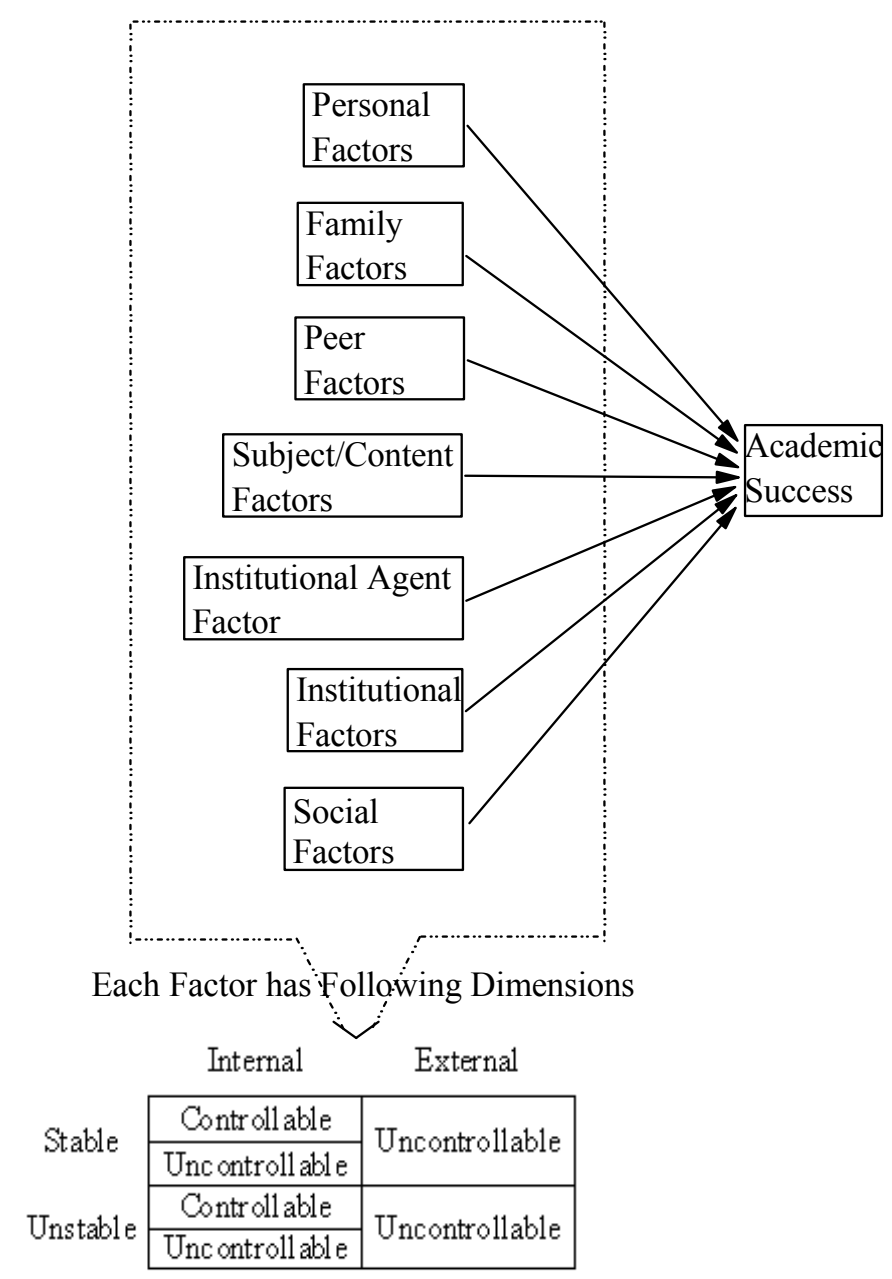

Figure 1. Proposed Generalized Framework

\section{Methodology - Two Surveys}

As mentioned previously, prior research studies have not considered student perceptions when examining the causal structure of factors that contribute to academic success or failure. Students may have been surveyed, but researchers theorized the causal dimensions and hypothesized the causal factors while students were passive objects used to test the theories or to validate hypotheses. The causal dimension structures were not necessarily identical among research studies nor are they necessarily the same as those of students. This study uses a more direct approach having students identify causal factors and then rank the factors they identified in conjunction with those identified in prior research studies. Given the exploratory nature of the study, we consider this study as our first phase in exploring a different approach to identify academic success factors. We started by conducting two surveys with small samples sizes. We hope that with a solid literature review and a fresh approach, this study will provide a framework and a list of factors for future studies. 


\section{Survey 1: A Survey to Identify Causal Factors for Academic Success}

To determine what factors are critical to academic success according to student perceptions, an open-ended paper-based survey was administered to 131 upper-level (third year or beyond) students at a university located in the southeastern United States. These students were enrolled in selected core courses in the three information technology (IT) related majors at the authors' institution: Information Systems, Information Technology, and Computer Sciences. The rationale for using upper division students is that they have the academic experience to recognize the factors that contribute to their academic successes or failures. Given the exploratory nature of this study, the sample is limited to students in IT-related programs. This sample was chosen as a matter of convenience.

The students were provided with a survey with 10 blanks and asked "What does it take to be successful in college? Please give ten factors that lead to academic success or failure." Responses were collected from 131 students. Content analysis was performed on the student responses. Content analysis involves making objective inferences from the students' responses and categorizing those responses (Strauss \& Corbin, 1990; Weber, 1985). Table 5 provides a compiled list of the factors identified by students as well as the percentage of students who cited that factor. Any factor that was identified by less than $5 \%$ of the students was eliminated for brevity.

Table 5: Factors Contributing To Academic Success or Failure Cited By Students

\begin{tabular}{|l|c|}
\hline \multicolumn{1}{|c|}{ Factors } & $\%$ \\
\hline Study & 55.73 \\
\hline Attend class & 42.75 \\
\hline See professors/ get to know them/ communicate/ availability & 41.98 \\
\hline Friends support/ make friends & 35.11 \\
\hline Time/task management & 31.30 \\
\hline Participate/ ask questions/ pay attention/ don't sleep in class & 27.48 \\
\hline Good professors (motivated, interesting, well-prepared) & 26.72 \\
\hline Balance between school, social life and home life & 25.19 \\
\hline Stress outlet (exercise, outside life, have fun, me time, etc.) & 24.43 \\
\hline Sleep & 23.66 \\
\hline Do homework (graded and ungraded), practice & 21.37 \\
\hline Commitment/Dedication/ Hard work & 19.85 \\
\hline Don't procrastinate/ Be Proactive & 19.85 \\
\hline Be organized & 17.56 \\
\hline Network (other students/mentors) & 16.79 \\
\hline Read & 16.03 \\
\hline Good notes/ take notes & 16.03 \\
\hline Use study groups & 14.50 \\
\hline Family support & 14.50 \\
\hline
\end{tabular}




\begin{tabular}{|l|c|}
\hline No financial concerns & 14.50 \\
\hline Extra-curricular activities (in school and outside) & 12.98 \\
\hline Group work/ teamwork & 12.21 \\
\hline Diet/ exercise & 12.21 \\
\hline Finding/ asking for help & 12.21 \\
\hline Flexible work schedule/ job or no job & 11.45 \\
\hline Focus & 10.69 \\
\hline Drug free/ no peer pressure/ limit or no alcohol & 9.92 \\
\hline Self-motivation/ Initiative & 9.16 \\
\hline Persistence/ perseverance/ desire & 9.16 \\
\hline Language barrier with professor & 9.16 \\
\hline Prioritize & 8.40 \\
\hline Set goals & 8.40 \\
\hline Choose appropriate major & 8.40 \\
\hline Reliable transportation & 7.63 \\
\hline Price of books (buy online, cheaper) & 6.87 \\
\hline Patience & 6.11 \\
\hline Positive attitude & 6.11 \\
\hline Good living environment (roommates, etc.) & 6.11 \\
\hline Tutors & 6.11 \\
\hline Discipline & 5.34 \\
\hline See advisor (academic, career, professor) & 5.34 \\
\hline Don't over schedule & 5.34 \\
\hline Have an academic plan & 5.34 \\
\hline Review for test provided (study guides, format of test) & 5.34 \\
\hline Types \& frequency of tests (multiple choice, essay, related to material) \\
\hline
\end{tabular}

\section{Survey 2: Students Rank the Factors Generated from the Literature and from Survey 1}

The factors identified in the first survey were combined with the factors identified in previous research studies to create the list of factors shown in Table 6 . To create the list of factors in Table 6 , the researchers did the following:

1. Reworded the factors, so the meanings of factors are clear and mutually exclusive.

2. Categorized the factors into groups of personal, course (subject/content), professor (institutional agent), college (institutional), and social. 
3. Within the personal factor group, formed subgroups using Weiner's dimensions of internal/external and controllable/uncontrollable of:

- personal traits or characteristics (personal - internal/uncontrollable),

- personal behaviors (personal - internal/controllable), and

- personal environment (personal -external/uncontrollable).

Students ranked the factors in each category by placing a 1 next to the factor which is the most important in that category, 2 next to the second most important, and so on. The survey was administered to 43 junior and senior students enrolled in upper level IT-related courses at a university located in the southeastern United States. The sample for this survey was independent of the first survey. The average ranking of each factor is presented in the second column of Table 6. The lower the average, the more important the factor is to academic success.

Table 6: Ranking Factors within Each Category

\begin{tabular}{|l|c|}
\hline \multicolumn{1}{|c|}{ Personal Traits or Characteristics (Internal/Uncontrollable) } & AVG \\
\hline Self-motivation/initiative & 2.47 \\
\hline Commitment and dedication & 2.93 \\
\hline Positive attitude, self esteem and confidence & 3.63 \\
\hline Persistence and perseverance & 4.05 \\
\hline Ability to focus under stress with distractions & 4.30 \\
\hline Patience & 5.16 \\
\hline Ability to communicate and interact within a group or a team & 5.49 \\
\hline \multicolumn{1}{|c|}{ Personal Behaviors (Internal/Controllable) } & 3.44 \\
\hline Attend class, pay attention, participate, and ask questions & 5.44 \\
\hline Study (invest time and effort in studying) & 6.47 \\
\hline Maintain a schedule and keep track of due dates and tasks & 7.53 \\
\hline Do assignments & 7.56 \\
\hline Manage stress (balance school work with exercise, hobbies, and social activities) & 8.16 \\
\hline Prioritize personal needs, school, work, family matters, and social activities & 8.72 \\
\hline Regular sleep and a healthy diet & 9.56 \\
\hline Choosing the appropriate major and understanding course requirements & 11.12 \\
\hline Have a well organized system of studying (read, review, summary, outline, self-test) & 11.70 \\
\hline Organized living environment and study materials & 12.77 \\
\hline Set up an academic plan from the start and stick with it & 10.74 \\
\hline Maintain a reasonable course load, balance easy courses with tough courses & \\
\hline Have limits to time spent partying, video gaming, drinking, etc. & \\
\hline Use study groups & (1) \\
\hline
\end{tabular}




\begin{tabular}{|c|c|}
\hline See professor outside class or during the office hours & 12.84 \\
\hline Gain work experience, hands-on experience, and internship in related fields & 13.67 \\
\hline Participate in extra-curricular activities (student associations, volunteer work, etc.) & 14.14 \\
\hline Exercise regularly & 14.33 \\
\hline No drugs or alcohol & 14.93 \\
\hline Practice religion and go to church & 15.88 \\
\hline \multicolumn{2}{|l|}{ Personal Environment (External/Uncontrollable) } \\
\hline Positive relationship, interaction, and support from friends & 5.07 \\
\hline Positive relationship, interaction, and support from family members & 6.26 \\
\hline $\begin{array}{l}\text { Good living environment (close to campus, clean, quiet, safe, computers and Internet ac- } \\
\text { cess, study rooms) }\end{array}$ & 6.40 \\
\hline Positive relationship, interaction, and support from faculty & 6.42 \\
\hline Positive relationship, interaction, and support from classmates & 6.95 \\
\hline Positive relationship, interaction, and support from roommates & 8.19 \\
\hline Positive relationship, interaction, and support from boyfriend/girlfriend & 8.63 \\
\hline $\begin{array}{l}\text { Positive relationship, interaction, and support from former students, mentors, advisors } \\
\text { and staff }\end{array}$ & 9.14 \\
\hline No financial problems & 9.14 \\
\hline Graduated from a good high school and got a solid foundation for college study & 9.56 \\
\hline No break-ups, personal or family problems & 10.21 \\
\hline Family members have no illness or health problems & 10.33 \\
\hline $\begin{array}{l}\text { Have no chronic diseases or disabilities (i.e., depression, alcoholism, drug addiction, mi- } \\
\text { graine headaches) }\end{array}$ & 10.51 \\
\hline Good part-time job with flexible work schedule & 11.23 \\
\hline No peer pressure for drugs or alcohol & 11.37 \\
\hline Have a reliable vehicle (no car breakdowns or traffic accidents) & 11.60 \\
\hline No involvement in legal cases & 11.67 \\
\hline \multicolumn{2}{|l|}{ Course (Subject/Content) } \\
\hline Clear course structure, informative syllabus, detailed schedule of exams and assignments & 2.42 \\
\hline Clear and fair grading policy & 4.40 \\
\hline Availability of study guide & 5.26 \\
\hline Reasonable expectation and level of difficulty & 5.53 \\
\hline $\begin{array}{l}\text { Reasonable number of exams and exams related to material covered with various types of } \\
\text { exam questions (multiple choice, short answer, essay) }\end{array}$ & 5.63 \\
\hline Good textbook & 6.09 \\
\hline
\end{tabular}




\begin{tabular}{|c|c|}
\hline Assignments in addition to exams & 6.60 \\
\hline Availability of lecture PowerPoint slides & 6.88 \\
\hline Extra credit opportunities & 7.14 \\
\hline $\begin{array}{l}\text { Integration of course with other courses(i.e., courses complement or extended other } \\
\text { courses, materials in a course can be related to those of others courses) }\end{array}$ & 7.86 \\
\hline Course requires group discussions and group projects & 8.26 \\
\hline \multicolumn{2}{|l|}{ Professor (Institutional Agent) } \\
\hline Instructor has a good personality, respects and motivates students, and is willing to help & 1.91 \\
\hline Instructor delivers interesting, informative, and well-prepared lectures & 2.16 \\
\hline $\begin{array}{l}\text { Instructor speaks English well and has no language barrier in communicating with stu- } \\
\text { dents }\end{array}$ & 2.49 \\
\hline Instructor has a PhD degree & 3.58 \\
\hline \multicolumn{2}{|l|}{ College (Institutional) } \\
\hline Location of the college, type of town and community, availability of local part-time jobs & 5.23 \\
\hline Accreditation and reputation of programs & 5.37 \\
\hline Variety of majors to choose from & 5.84 \\
\hline Courses offered every semester with multiple sessions to choose from & 6.42 \\
\hline $\begin{array}{l}\text { Quality and availability of computer labs, wired and wireless networks, computing } \\
\text { equipment, library and library book collection on campus }\end{array}$ & 7.23 \\
\hline Availability of scholarships and financial aid & 7.28 \\
\hline Academic and career advising & 8.05 \\
\hline Environment provided through classrooms, campus buildings, and campus design & 9.91 \\
\hline Availability of tutors & 10.72 \\
\hline Presence of international students on campus & 10.91 \\
\hline Availability of online courses as well as offline courses & 11.05 \\
\hline Campus cultural events, speakers, shows, art exhibitions & 11.16 \\
\hline School provided means of transportation and parking facilities & 11.21 \\
\hline Availability of study abroad programs and international exchange programs & 11.42 \\
\hline School managed dormitories, their locations and environments & 11.60 \\
\hline Quality of health clinic and health insurance & 12.21 \\
\hline Quality and availability of RAC facilities & 12.84 \\
\hline School athletic programs and sports teams & 12.88 \\
\hline
\end{tabular}




\begin{tabular}{|l|c|}
\hline \multicolumn{1}{|c|}{ Social } & \\
\hline Economic condition of the United States & 2.47 \\
\hline Trends of society and technology & 3.07 \\
\hline Crime rate in the community & 3.67 \\
\hline World peace, no wars and conflicts outside the United States & 4.16 \\
\hline Content and quality of national TV programs, movies, and news media & 4.84 \\
\hline Role models in the society & 4.88 \\
\hline Republican or Democrat Federal Government & 5.02 \\
\hline
\end{tabular}

\section{Discussion of Findings}

Based on the rankings in Table 6, the most important personal internal factors are related to motivation, commitment, participation, and studying while the most important external factors are support of family and friends. The highest ranked social factor is the U.S. economy, which may be related to the current poor economic conditions in the U.S. The most important institutional factor is the location of the university, availability of jobs, and type of community or town. This last factor may be partially be explained by the location of the respondents, a small, rural town in the southeastern U.S. where the job market is poor. There are also several highly ranked factors related to the professor and to the course.

A closer examination of the results and in depth discussion is provided below. The key findings are discussed, related to previous research, and used to identify future research issues. These key findings are discussed in light of the students' internal locus of control, students' motivation and emotional IQ, team work, quality of teaching, and specific aspects of the university budget.

\section{Difference between Factors Identified by Students and Literature}

The most notable difference between factors identified by students and those discussed in the literature is the fact that students did not mention intelligence in Survey 1. One explanation is that the students consider intelligence as a default factor and saw no need to mention it. The alternative explanation is that the students do not consider intelligence important. A study by Goleman (1995) is in agreement with the alternative explanation suggesting that IQ alone is not sufficient for measuring success; it only counts for $20 \%$, and the rest is explained by emotional and social intelligence and luck.

Overall, the factors listed by students were discussed in the literature, but the factors found in the literature were typically at a different level of granularity. For example, effort was a factor examined in many studies. However, students did not list effort, but instead listed activities that required effort like studying, attending class, reading, taking good notes, and doing homework. There was one factor that was not explicitly listed in the literature and that was that a review for the exam was provided.

There are several factors examined in the literature that students did not list. These factors relate more to policy (on retention, suspension, etc.), learning styles, and university and societal factors (i.e., the economy, campus climate, success of athletic programs, etc.).

\section{Internal Locus of Control}

Locus of control is a term from social psychology developed by Rotter (1954) that refers to the degree to which individuals think that they control events that affect them. Individuals with an 
internal locus of control believe their own actions and behavior are the primary cause of events that happen to them. Many students cited events under their control more frequently in the first study (see Table 5) indicating an internal locus of control as it relates to academic success. In the first survey, where each student gave 10 factors related to academic success, the majority of the factors identified by students are factors within their control such as study, attend class, see professors, time management, and participate. Students only mentioned a few non-personal factors, such as availability of professors and friends' support in the group of most-often cited factors. In the second study, the item relating to an internal locus of control orientation are those that are labeled personal/internal/controllable in Table 6 . The evidence from both surveys indicates that students have an internal locus of control orientation and believe that they have a direct impact on their learning and academic success through the time and effort they invest.

\section{Motivation and Emotional IQ}

In Survey 2 (ranking factors within each group), motivation was ranked as the most important factor in the group of Personal Traits and Characteristics. Intelligence and degree of motivation have been theoretically suggested as the most essential factors in academic achievement (Dweck, 1986; Harris, 1940) and experimentally verified by several studies, including a longitudinal study by Anderson and Keith (1997). Motivation is part of the larger concept of emotional intelligence.

Emotional intelligence is defined as the ability to understand, feel, manage, and guide one's own or others' emotions (Goleman, 1995). Emotional intelligence has been found to be associated with academic achievement, workplace performance, and business success (Cherniss \& Goleman, 2001; Deniz, Tras, \& Aydogan, 2009). Factors identified by students in the first study (Table 5) related to emotional intelligence are time/task management, commitment/dedication/hard work, don't procrastinate, be organized, self-motivation, and persistence. In the second study, factors related to emotional IQ are those that are labeled personal/internal/uncontrollable in Table 6. Based on the literature and our findings, emotional intelligence is a key to student perceptions about academic success.

\section{Quality of Teaching}

In ranking factors related to professors, students ranked "Instructor has a good personality, respects and motivates students, and is willing to help" and "Instructor delivers interesting, informative, and well-prepared lectures" as the two most important factors (Table 6) and had the least concern with the academic degree of their instructors. Personality, motivation, willingness to help, and delivering good lectures are factors that contribute to the overall quality of teaching, but are by no means the only factors that contribute to quality teaching. The importance of personality, motivation, and willingness to help confirms some of the findings of previous studies in which teacher quality and teacher experience have a positive relationship with student achievement (Greenwald et al., 1996; Hanushek, 1996).

In addition, in the first survey, "See professors" and "Good professors" were cited as the third and seventh most important factors out of 45 total factors identified by more than $5 \%$ of students surveyed (Table 5). In the Personal Environment category of the second survey, students ranked the importance of relationship in this order: friends, family members, faculty, classmates, roommates, and boyfriend/girlfriend (Table 6). This result indicated that relationship with faculty is more important to students than relationships with classmates, roommates, boyfriends or girlfriends with regards to perceptions about academic success. 


\section{Team Work}

Students ranked the factors related to team work low. "Ability to communicate and interact within a group or a team" in Personal Traits or Characteristics was ranked $7^{\text {th }}$ out of 7. "Use study groups" in Personal Behaviors was ranked $14^{\text {th }}$ out of 20 . "Course requires group discussions and group projects" in Course was ranked $11^{\text {th }}$ out of 11 . Although many IT-related courses are designed with group projects or team work, students do not believe that the group projects help academic success. This result is not consistent with evidence reported in the literature. Team-based learning is advocated by many educators and has successfully been put into practice by Michaelsen, Knight, and Fink (2002) in a traditional environment and by Gomez, Wu, and Passerini (2010) in a computer-aided environment.

\section{Recommendations}

As stated in the introduction, enrollments in IT-related degree programs are declining while demand for jobs in IT-related fields is projected to increase. Retention of students already enrolled in these degree programs is of the utmost importance. There are a few items highlighted in this study coupled with other research efforts that can be used in discussions about how to retain students in IT-related programs. The results of this research provide several insights based on student perceptions of factors relating to their academic success. The insights are discussed and recommendations are made at the institutional level and at the classroom and instructor level.

\section{Recommendations for the Institution}

There are several factors ranked highly by students related to the professor and to the course. This indicates that students believe that the quality of instruction is vital to academic success. Fortunately, factors related to instructional quality are under the control of the instructor and the university. If universities value high quality instruction, they should continue to invest in the professional development of their educators. In order to attract and retain high quality educators, institutions must determine how to measure teaching quality, how to reward high quality teaching, and how to balance teaching and research.

To measure teaching in higher education, the student evaluation of faculty (SEF) is commonly used to assess quality of teaching. However, empirical studies have found a positive correlation between a student's expected grade and the resulting SEF (Zangenehzadeh, 1988). Using SEF for faculty salary, promotion, and tenure decisions pressures faculty to comply with student demands regarding teaching style and grading. Weller (1984) reported that using SEF was one of the two main reasons for grade inflation. Haskell (1998) went on and suggested that using SEF infringes academic freedom and the quality of instruction. Does SEF measure student academic success and improve quality of education? Perhaps a more direct measurement of student achievement should be used in addition to SEF.

Research is the core mission of many universities as it is a strategy for funding higher education. Therefore, research is a factor for evaluating and compensating faculty (Sutton \& Bergerson, 2001). Faculty salary increases and promotion decisions are typically based on research, teaching, and service. Studies show that faculty research productivity is strongly correlated with salary, and teaching at the graduate level is positively correlated with salary, whereas teaching at the undergraduate level is negatively correlated (Massy \& Wilger, 1995). Some research universities have been criticized for not paying adequate attention to undergraduate teaching (Bok, 1992). As the quality of teaching and structure of the course is important to students with regards to academic success, a way of balancing the reward for good teaching with that of good research needs to be addressed at the institutional level. 


\section{Recommendations for Faculty}

There are several factors cited as important by students and in the literature, such as quality of instructor, locus of control, team work, relationship between faculty and students, and emotional intelligence, on which faculty have some control through professional development, classroom design, and curriculum development.

According this study, faculty who are well prepared, willing to help, motivating, interesting, and informative contribute highly to student perceptions of academic success. In addition, faculty who design courses with clear structure and lay out syllabi clearly also contribute to students' perceptions of academic success. It could be argued that faculty who are interesting, motivating, and informative can potentially enhance their students' personal motivation/initiative and commitment/dedication, which are cited as important by students. It is important that faculty continue to improve teaching methods and course design as both make a difference in the perceptions of academic success for students.

The result of these two surveys reconfirmed the findings in previous studies of the importance of emotional intelligence. Therefore, faculty should be concerned about emotional intelligence as well as technical intelligence and incorporate both emotional intelligence and technical intelligence in curriculum development and in program assessment criteria.

In the second survey, faculty are perceived as more important in contributing to academic success than classmates, roommates, boyfriends, or girlfriends (see Table 6). At the same time, the survey indicates that students have an internal locus of control orientation and believe that they have a direct impact on their learning and academic success. This potentially puts more demand on faculty to manage and motivate students without violating students' internal locus of control and creating resistance to authority. Emerson (1962) gave some suggestions to handle the powerdependence relationships between faculty and students. To apply Emerson's suggestions in an academic context, faculty should:

- Clearly define rules and requirements ensuring that they are easily enforceable by the instructor and easily followed by students.

- Have clearly defined policies for dealing with students who reject the rules and requirements or who fail to participate,

- Provide incentives for student conformance to the rules.

- Provide incentives for forming positive coalitions or study groups as peer pressure is potentially more powerful than the power of instructor alone.

- Recognize differences and handle students differently since students with a predominately external locus of control orientation are likely to accept external manipulation and conform to imposed norms and expectations while students with an internal locus of control orientation are more conducive to high achievement and independent functioning, but resist submitting to authority (Spector, 1983).

The fact that students do not see team work as important to their academic success, as indicated by their low ranking of team work in the second survey (see Table 6), is troubling. The ability to work in teams is imperative, especially in the IT industry. In a study by Aasheim, Williams and Butler (2009), IT managers ranked the ability to work in teams $3^{\text {rd }}$ overall in a list of 32 skills and traits of important for entry-level IT workers while communication skills were ranked $2^{\text {nd }}$ and interpersonal skills in general were the highest ranking category. The disconnect between student perceptions and the actual importance of working in teams is not necessarily a function of the amount of team work required in IT-related degrees, but perhaps more a function of the quality and scope of team-based projects. Perhaps students do not see projects of sufficient scope or 
depth to recognize the value of team work. In addition, as educators, we may wait until too late in students' academic careers to involve them in team based exercises. In this study, students frequently cite getting to know faculty, meeting friends, and support from friends, family and faculty as important. Therefore, importance of social interaction is important to students participating in this survey in IT-related degree programs. Social activities will provide students with the opportunity to meet professors and feel comfortable approaching them and to meet other students and establish partnerships, friendships, and perhaps teammates.

\section{Conclusion, Limitations, and Future Research}

The goals of this research project were to (1) unify the existing research in to a cohesive, comprehensive framework, (2) to add the voice of the student to the factors that had been hypothesized and confirmed in prior research, (3) to incorporate the factors identified by students in to the framework that was proposed, and (4) to have students rank the factors as they related to academic success. These goals were accomplished by first administering an open-ended survey to students asking them what was important to their academic success or failure. The most often cited factors by students were then combined with the factors identified in prior research and all factors were categorized using a subset of the newly proposed framework. Students were then asked to rank each factor within each category.

The results of the ranking provided confirmation that certain factors related to the professor are consistently cited as the most important when related to academic success. Students value instructors that are interesting, well prepared, and informative as well as those that have a clear course structure. The findings in this study indicate that:

- Generally students have an internal locus of control when it comes to academic success.

- Motivation and emotional intelligence are factors that students consider important to academic success.

- The faculty member teaching the course is an important factor in the student's academic success.

- Students did not seem to think working in teams as greatly contributing to their academic success.

Further research is needed to verify the proposed generalized framework, such as confirmatory factor analysis. In order to compare across the proposed groupings of factors, a study where students provide an overall ranking of several of the top factors of each group is needed. The survey needs to be administered to non-IT students to see if there are differences between IT students and non- IT students. As the instructor plays an important role in student success according the students' perceptions and the literature reviewed, a future study on the importance of instructor involvement with students in the classroom and outside the classroom as well as indicators of qualities of instructors that are successful in the classroom (such as teaching style, involvement in research, and personality characteristics) would be beneficial.

The limitations of this research include that students surveyed were from a single university, all students were enrolled in courses in IT-related degree programs, and the sample size for the second survey was relatively small. A broader study would need to be conducted to see if the results do indeed generalize when including a larger sample of students from more universities.

Another limitation is that, in the study, academic success is not defined for students. Therefore, different students may have different definitions of academic success. A student might define success differently than a faculty member or an administrator. Academic success indicators include, but are not limited to, graduation rate, retention rate, annual salary the first year after grad- 
uation, and placement percentage. Depending on how success is defined, the factors that are important to success could vary.

\section{References}

Aasheim, C. L., Williams, S., \& Butler, E. S. (2009). Knowledge and skill requirements for IT graduates: A survey of it workers and managers. Journal of Computer Information Systems, 42, 690-699.

Anderson, E. S., \& Keith, T. Z. (1997). A longitudinal test of a model of academic success for at-risk high school students. Journal of Educational Research, 90(5), 259-268.

Aysan, F., Tanrı̈̈̆gen, G., \& Tanrı̈ğen, A. (1996). Perceived causes of academic failure among the students at the faculty of education at Buca. U. S. Department of Education. (ERIC Document Reproduction Service No. ED406326)

Blumberg, P. (1984). Predicting student success from non-cognitive variables. Paper presented at the 1984 Annual Meeting of the American Educational Research Association. (ERIC Document Reproduction Service No. ED243970)

Boekaerts, M., Otten, R., \& Voeten, R. (2003). Examination performance: Are student's causal attributions school-subject specific? Anxiety, Stress \& Coping, 16(3), 331-342.

Bok, D. (1992). Reclaiming the public trust. Change, 24(4), 12-19.

Bowman, L. J. (2005). Grade retention: Is it a help or hindrance to student academic success? PreventingSchool Failure, 49(3), 42-46.

Brookshire, R. G., Crews, T. B., \& Brown, H. F., III. (2009). Student success in a university introductory networks and telecommunications course: Contributing factors. International Journal of Information and Communication Technology Education, 5(1), 53-61.

Bruinsma, M., \& Jansen, E. (2007). Educational productivity in higher education: An examination of part of the Walberg educational productivity model. School Effectiveness and School Improvement, 18(1), 45-65.

Bureau of Labor Statistics, U.S. Department of Labor. (2010a). Computer and information systems managers. Occupational Outlook Handbook, 2010-11 Edition. Retrieved from http://www.bls.gov/oco/ocos258.htm

Bureau of Labor Statistics, U.S. Department of Labor. (2010b). Computer network, systems and database administrators. Occupational Outlook Handbook, 2010-11 Edition. Retrieved from http://www.bls.gov/oco/ocos042.htm

Cherniss, C., \& Goleman D. (2001). The emotionally intelligent workplace: How to select for, measure, and improve emotional intelligence in individuals, groups, and organizations. CA: Jossey-Bass.

Connolly, J., \& McGrail, J. (1978). School variables affecting student learning. National Institute of Education, Washington, DC. (ERIC Document Reproduction Service No. ED179555)

Costrell, R., Hanushek, E., \& Loeb, S. (2008). What do cost functions tell us about the cost of an adequate education? Peabody Journal of Education, 83(2), 198-223.

Daniels, E., \& Arapostathis, M. (2005). What do they really want? Student voices and motivation research. Urban Education, 40(1), 34-59.

Demeulemeester, J., \& Rochat, D. (1995). Impact of individual characteristics and sociocultural environment on academic success. International Advances in Economic Research, 1(3), 278-288.

Deniz, M. E., Tras, Z., \& Aydogan, D. (2009). An investigation of academic procrastination, locus of control, and emotional intelligence. Educational Sciences: Theory and Practice, 9(2), 623-632.

Denton, J. J., Morris, J. E., \& Tooke, D. (1981). Academic characteristics of student teachers and cognitive attainment of their learners. Paper prepared for the Annual Meeting of the Association of Teacher Educators. (ERIC Document Reproduction Service No. ED199195) 
Dweck, C. S. (1986). Motivational processes affecting learning. American Psychologist, 41(10), 10401048.

Ehrenberg, R., Brewer, D., Gamoran, A., \& Willms, J. (2001). Class size and student achievement. Psychological Science in the Public Interest, 2(1), 1-30.

Emerson, R. M. (1962). Power-dependence relations. American Sociological Review, 27(1), 31-41.

Feick, D., \& Rhodewalt, F. (1997). The double-edged sword of self-handicapping: Discounting, augmentation, and the protection and enhancement of self-esteem. Motivation and Emotion, 21(2), 147-163.

Fernandez, M. E., Campbell, K.., \& Honess, K. (2000). NC families and communities equals success (faces): Six months later. 13th Annual Conference Proceedings-A System of Care for Children's Mental Health: Expanding the Research Base, 123-126.

Goleman, D. (1995). Emotional intelligence: Why it can matter more than IQ. New York, NY: Bantam Books.

Gomez, E., Wu, D., \& Passerini, K. (2010). Computer-supported team-based learning: The impact of motivation, enjoyment and team contributions on learning outcomes. Computers \& Education, 55(1), 378390 .

Gradstein, M., \& Justman, M. (2000). Human capital, social capital, and public schooling. European Economic Review, 44(4-6), 879-890.

Greenwald, R., Hedges, L., \& Laine, R. (1996). The effect of school resources on student achievement. Review of Educational Research, 66(3), 361-396.

Grossman, M. (2008). The relationship between health and schooling. Eastern Economic Journal, 34(3), 281-292.

Hanushek, E. A. (1996). A more complete picture of school resource policies. Review of Educational Research, 66(3), 397-409.

Hanushek, E. A., \& Kimko, D. (2000). Schooling, labor force quality, and the growth of nations. American Economic Review, 90(5), 1184-1208.

Hanushek, E. A., \& Raymond, M. F. (2005). Does school accountability lead to improved student performance? Journal of Policy Analysis \& Management, 24(2), 297-327.

Hanushek, E. A., \& Wößmann, L. (2006). Does educational tracking affect performance and inequality? Differences- in-differences evidence across countries. Economic Journal, 116(510), C63-C76.

Harris, D. (1940). Factors affecting college grades: a review of the literature, 1930-1937. Psychological Bulletin, 37(3), 125-166.

Haskell, R. E. (1998). Academic freedom, tenure, and student evaluation of faculty: Galloping polls in the 21st century. ERIC/AE Digest. (ERIC Document Reproduction Service No. ED426114)

Henry, J., Martinko, M., \& Pierce, M. (1993). Attributional style as a predictor of success in a first computer science course. Computers in Human Behavior, 9(4), 341-352.

Howard, R. D., Borland, K., Johnson, C., \& Baker, L. J. (2001). Academic success of suspended students. AIR 2001 Annual Forum, 2-19.

Hulse, J. A., Chenowith, T., Lebedovych, L., Dickinson, P., Cavanaugh, B., \& Garrett, N. (2007). Predictors of student success in the U.S. army graduate program in anesthesia nursing. AANA Journal, 75(5), 339-346.

Kevin, R. C. \& Liberty, P. G., Jr. (1975). Students' personality, attitude, and learning style as predictors of performance in an undergraduate organic chemistry course using computer-based education. U.S. Educational Resources Information Center, (ERIC Document Reproduction Service No.ED115209)

Kinshuk, T., \& McNab, P. (2006). Cognitive trait modeling: the case of inductive reasoning ability. Innovations in Education and Teaching International, 43(2), 151-161. 
Kovenklioglu, G. \& Greenhaus, J. H. (1978). Casual attributions, expectations, and task performance. Journal of Applied Psychology, 63(6), 698-705.

Lackaye, T. D., \& Margalit, M. (2006). Comparisons of achievement, effort, and self-perceptions among students with learning disabilities and their peers from different achievement groups. Journal of Learning Disabilities, 3(5), 432-446.

Massy, W. F., \& Wilger, A. (1995). Improving productivity: What faculty think about it and its effect on quality. Change, 27(4), 10-21.

Mathews, J. G., \& Hackett, E. R. (1997, November). The Alabama superintendent's report card: An analysis of local education agency characteristics and success at meeting state defined performance measures. Paper presented at the Annual Meeting of the Mid-South Educational Research Association, (ERIC Document Reproduction Service No. ED415254)

Matuszek, P. \& Haskin, C. (1978). Who are the disadvantaged and what should we do for them? The relationship of family variables to achievement and some implications for educational programming. Paper presented at the Annual Meeting of the American Educational Research Association. (ERIC Document Reproduction Service No. ED171438)

Mayer, M. J. \& Patriarca, L. A. (2007). Behavioral scripts and instructional procedures for students with learning and behavioral problems. Preventing School Failure, 52(1), 3-12.

McGregor, A. (2007). Academic success, clinical failure: Struggling practices of a failing student. Journal of Nursing Education, 46(11), 504-515.

McKenzie, K., \& Schweitzer, R. (2001). Who succeeds at university? Factors predicting academic performance in first year Australian university students. Higher Education Research and Development, 20(1), 21-33.

Mehrabian, A. (1968). Male and female scales of the tendency to achieve. Educational and Psychological Measurement, 28(2), 493-502.

Melby, J. N., \& Conger, R. D. (1996). Parental behaviors and adolescent academic performance: A longitudinal analysis. Journal of Research on Adolescence, 6(1), 113-37.

Meyer, J., \& Koelbl, S. (1982). Students' test performances: Dimensionality of causal attributions. Personality and Social Psychology Bulletin, 8(1), 31-36.

Michaelsen, L. K., Knight, A. B., \& Fink, L. D. (2002). Team-based learning: A transformative use of small groups. London: Praeger Publishers.

Mixon, F. G., \& Treviño, L. J. (2005). From kickoff to commencement: The positive role of intercollegiate athletics in higher education. Economics of Education Review, 24(1), 97-102.

Niemczyk, M. C., \& Savenye, W. C. (2001). The relationship of student motivation and self-regulated learning strategies to performance in an undergraduate computer literacy course. Proceedings of the $24^{\text {th }}$ National Convention of the Association for Educational Communications and Technology, 312322.

Nonis, S. A. \& Hudson, G. I. (2010). Performance of college students: Impact of study time and study habits. Journal of Education for Business, 85, 229-238.

President's Council of Advisors on Science and Technology. (2007). Leadership under challenge: Information technology $R \& D$ in a competitive world. Retrieved from http://www.nitrd.gov/pcast/reports/PCAST-NIT-FINAL.pdf

Ritchey, F., \& Lewis, B. (1986). A statistical interaction model for examining compensatory effects on academic performance. Proceedings of the 15th Annual Meeting of the Mid-South Educational Research Association. (ERIC Document Reproduction Service No. ED310164)

Roberts, G., \& Pascuzzi, D. (1979). Causal attributions in sport: some theoretical implications. Journal of Sport Psychology, 1(3), 203-210. 
Ross, J., Drysdale, M., \& Schulz, R. (2001). Cognitive learning styles and academic performance in two postsecondary computer application courses. Journal of Research on Computing in Education, 33(4), 400-412.

Rotter, J. B. (1954). Social learning and clinical psychology. NY: Prentice-Hall.

Schoeneman, T., \& Curry, S. (1990). Attributions for successful and unsuccessful health behavior change. Basic and Applied Social Psychology, 11(4), 421-431.

Seay, C. (2004). Using a "socio-cultural" approach in teaching information technology to African American students with academic difficulties. Journal of Information Technology Education, 3, 83-102. Retrieved from http://www.jite.org/documents/Vol3/v3p083-102-103.pdf

Shelton, E. (2003). Faculty support and student retention. Journal of Nursing Education, 42(2), 68-76.

Spector, P. E. (1983). Locus of control and social influence susceptibility: Are externals normative or informational conformers? Journal of Psychology, 115(2), 199-201.

Sutton, T., \& Bergerson, P. (2001). Faculty compensation systems: Impact on the quality of higher education. ASHE-ERIC Higher Education Report, 28(2), 15-24.

Strauss, A., \& Corbin, J. (1990). Basics of qualitative research: Grounded theory procedures and techniques. Newbury Park, CA: Sage.

Volkwein, J. F., Valle, S., Parmley, K., Blose, G., \& Zhou, Y. (2000). A multi-campus study of academic performance and cognitive growth among native freshman, two-year transfers, and four-year transfers. Paper presented at the Annual Forum for Institutional Research. (ERIC Document Reproduction Service No. ED445652)

Weber, R. (1985). Basic content analysis. Beverly Hills, CA: Sage Publications.

Weiner, B. (1974). Achievement motivation and attribution theory. Morristown, NJ: General Learning Press.

Weiner, B. (1979). A theory of motivation for some classroom experiences. Journal of Educational Psychology, 71(1), 3-25.

Weller, L. D. (1984). Attitude toward grade inflation: A survey of private and public colleges of education. Journal of Research and Development in Education, 18(1), 51-56.

Wince, M. H., \& Borden, V. (1995). When does student satisfaction matter? Paper presented at the Annual Forum for Institutional Research. (ERIC Document Reproduction Service No. ED386990)

Yan, W., \& Gaier, E. (1994). Causal attributions for college success and failure: An Asian-American comparison. Journal of Cross-Cultural Psychology, 25(1), 146-158.

Zangenehzadeh, H. (1988). Grade inflation: A way out. Journal of Economic Education, 19(3), 217-26.

Zhang, Z., \& RiCharde, R. (1997). Learning-thinking style inventory: LISREL and multivariate analyses. Paper presented at the Annual Meeting of the American Educational Research Association. (ERIC Document Reproduction Service No. ED410264) 


\section{Biographies}

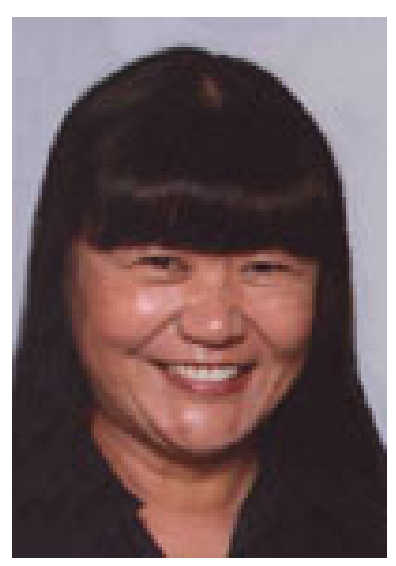

Aimao Zhang is an associate professor of Information Technology at Georgia Southern University. She received her PHD in Management Information Systems from Southern Illinois University at Carbondale. Her teaching specialties are in server-side programming, web application design and development. Her research interests include IT education, e-commerce, industrial economics, business ethics, banking and finance studies.

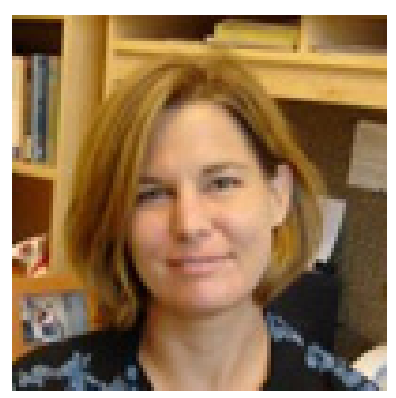

Cheryl L. Aasheim is an associate professor of Information Technology at Georgia Southern University. She received her B.S. and M.S.T. degrees in Mathematics from University of Florida in 1991 and 1993, respectively. She received her Ph.D. in Decision and Information Sciences in 2002 from the University of Florida. Her research interests include I.T. skills research, ethics in IT, IT education, curriculum development, and assessment. 